\title{
PENGARUH KUALITAS PELAYANAN, BRAND IMAGE DAN CUSTOMER RELATIONSHIP MANAGEMENT TERHADAP LOYALITAS PELANGGAN INDOMARET KELURAHAN PADURENAN, BEKASI TIMUR
}

\author{
Muhammad Lutfi Rizaldi \\ Resti Hardini \\ Email: 1utfirizaldi21@gmail.com, resti.hardini@yahoo.com \\ Program Studi Manajemen Fakultas Ekonomi \\ Universitas Nasional
}

\begin{abstract}
ABSTRAK
Penelitian ini bertujuan untuk menguji dan menganalisis pengaruh kualitas pelayanan, brand image dan customer relationship management terhadap loyalitas pelanggan Indomaret Kelurahan Padurenan, Bekasi Timur. Jenis data yang digunakan adalah data primer yang diperoleh dari penyebaran kuesioner kepada responden. Populasi yang digunakan dalam penelitian ini adalah pelanggan Indomaret Kelurahan Padurenan, Bekasi Timur. Sampel penelitian terdiri dari 100 responden. Penelitian ini menggunakan metode analisis regresi linear berganda. Hasil penelitian menunjukkan bahwa kualitas pelayanan, brand image dan customer relationship management secara parsial berpengaruh positif dan signifikan terhadap loyalitas pelanggan Indomaret Kelurahan Padurenan, Bekasi Timur.
\end{abstract}

Kata kunci: Kualitas pelayanan, brand image, customer relationship management, loyalitas pelanggan

\begin{abstract}
This study aims to test and analyze the influence of service quality, brand image and customer relationship management on customer loyalty of Indomaret in Padurenan, East Bekasi. Data type that used is primary data that obtained from distribution of the questionnaires to respondents. Population that used in this study is customers of Indomaret in Padurenan, East Bekasi. Samples of the study contained of 100 respondents. This study used multiple linear regression method. Results of the study showed that service quality, brand image and customer relationship management has positive and significant effect on customer loyalty of Indomaret in Padurenan, East Bekasi.
\end{abstract}

Keywords: Service quality, brand image, customer relationship management, customer loyalty

\section{PENDAHULUAN}

Kemajuan di bidang perekonomian telah memicu pesatnya perkembangan dunia bisnis. Hal tersebut banyaknya bermunculan perusahaan dan entitas bisnis di berbagai sektor yang saling berkompetisi untuk menguasai pasar dan industrinya masing-masing. Salah satu sektor perusahaan yang mengalami perkembangan yang pesat dengan persaingan yang ketat adalah sektor retail. Setiap perusahaan senantiasa berusaha untuk menawarkan produk berkualitas tinggi kepada pelanggannya dengan pelayanan yang berkualitas tinggi pula. 
Di tengah persaingan yang ketat, salah satu kunci untuk menjaga eksistensi suatu perusahaan adalah loyalitas pelanggan. Perusahaan dengan pelanggan berloyalitas tinggi cenderung dapat eksis di industri dalam jangka waktu yang lebih lama dibandingkan perusahaan dengan konsumen dan pelanggan berloyalitas rendah. Tingginya loyalitas pelanggan menyebabkan pelanggan tersebut melakukan pembelian secara berulang-ulang terhadap produk/jasa dari suatu perusahaan. Hal tersebut pada akhirnya akan memelihara eksistensi suatu perusahaan dalam jangka panjang.

Bagi perusahaan di sektor jasa, kualitas pelayanan merupakan hal yang sangat menentukan kepuasan pelanggan. Perusahaan dituntut untuk senantiasa memberikan pelayanan berkualitas tinggi agar dapat memberikan kepuasan bagi pelanggannya sehingga pelanggan tersebut menjadi loyal kepada perusahaan. Hasil penelitian yang dilakukan oleh Pramana dan Rastini (2016) membuktikan bahwa kualitas pelayanan berpengaruh positif dan signifikan terhadap loyalitas pelanggan. Menurut Kotler dan Keller (2009), kualitas pelayanan yang baik akan menimbulkan kepuasan konsumen yang akan mendorong konsumen tersebut untuk melakukan pembelian ulang. Hal tersebut pada akhirnya akan meningkatkan loyalitas konsumen.

Salah satu faktor lain yang dapat mempengaruhi loyalitas pelanggan adalah citra merek (brand image). Sondakh (2014) menemukan bahwa citra merek berpengaruh positif dan signifikan terhadap loyalitas pelanggan. Setiadi (2003) dalam Sondakh (2014) menyatakan bahwa suatu merek bercitra positif akan menarik konsumen untuk melakukan pembelian dan pembelian ulang. Hal tersebut pada akhirnya akan meningkatkan loyalitas konsumen.

Hasil penelitian Mulyaningsih (2013) menunjukkan bahwa customer relationship management juga berpengaruh positif dan signifikan terhadap loyalitas pelanggan. Menurut Alma (2011), Customer Relationship Management (CRM) merupakan proses untuk mendapatkan, mempertahankan dan meningkatkan hubungan yang menguntungkan dengan pelanggan dalam rangka menciptakan nilai dan kepuasan pelanggan. Hubungan yang baik antara perusahaan dan pelanggan akan menciptakan kepuasan pelanggan dan mendorong timbulnya loyalitas pelanggan tersebut terhadap perusahaan.

Tingginya persaingan di sektor retail dan minimarket menyebabkan perusahaanperusahaan di sektor tersebut bersaing untuk memperoleh predikat top brand dari masyarakat. Hal ini dikarenakan predikat tersebut mencerminkan bahwa merek yang bersangkutan merupakan merek terbaik pilihan konsumen (Top Brand Award, 2017). Berikut ini merupakan tabel top brand index untuk kategori minimarket pada tahun 2012-2016. 
Tabel 1. Top Brand Index Kategori Minimarket Tahun 2012-2016

\begin{tabular}{|c|c|c|c|c|c|}
\hline \multirow{2}{*}{ Merek } & \multicolumn{5}{|c|}{ Top Brand Index } \\
\cline { 2 - 6 } & $\mathbf{2 0 1 2}$ & $\mathbf{2 0 1 3}$ & $\mathbf{2 0 1 4}$ & $\mathbf{2 0 1 5}$ & $\mathbf{2 0 1 6}$ \\
\hline Alfamart & $51,7 \%$ & $48,8 \%$ & $52,1 \%$ & $52,9 \%$ & $46,4 \%$ \\
\hline Indomaret & $36,9 \%$ & $43,3 \%$ & $41,5 \%$ & $40,6 \%$ & $47,0 \%$ \\
\hline Alfamidi & $3,1 \%$ & $2,3 \%$ & $2,1 \%$ & - & - \\
\hline Yomart & $1,4 \%$ & - & - & - & - \\
\hline
\end{tabular}

(Sumber: Top Brand Award, 2017)

Berdasarkan tabel di atas, Indomaret mengalami fluktuasi top brand index pada tahun 2012-2016. Pada tahun 2012-2015, Alfamart justru memiliki top brand index yang lebih tinggi daripada Indomaret. Fluktuasi top brand index yang dialami oleh Indomaret mencerminkan bahwa loyalitas pelanggan Indomaret cenderung masih berfluktuasi. Oleh karena itu, perlu dilakukan penelitian untuk menganalisis faktor-faktor yang dapat mempengaruhi loyalitas pelanggan Indomaret. Dalam hal ini, penelitian ini akan menguji dan menganalisis pengaruh kualitas pelayanan, brand image dan customer relationship management terhadap loyalitas pelanggan Indomaret Kelurahan Padurenan, Bekasi Timur. Hasil dari penelitian ini diharapkan dapat menjadi bahan pertimbangan bagi perusahaan dalam menentukan strategi yang tepat untuk memelihara dan meningkatkan loyalitas pelanggan.

\section{TINJAUAN PUSTAKA}

\section{Pengertian Kualitas Pelayanan}

Menurut Ratnasari dan Aksa (2016), kualitas pelayanan merupakan perbedaan antara ekspektasi dan harapan pelanggan atas pelayanan yang diterimanya. Lupiyoadi (2014:216) mendefinisikan kualitas pelayanan sebagai kemampuan perusahaan dalam memberikan pelayanan kepada pelanggan. Sementara itu, Tjiptono dan Chandra (2012) mengartikan kualitas layanan sebagai ukuran atas seberapa bagus pelayanan yang diberikan perusahaan dan seberapa sesuai layanan yang diberikan tersebut dengan ekspektasi pelanggan.

Kualitas pelayanan merupakan upaya pemenuhan kebutuhan dan keinginan konsumen serta ketepatan penyampaiannya dalam mengimbangi harapan konsumen. Kualitas pelayanan dapat diartikan sebagai tingkat keunggulan yang diharapkan dan pengendalian atas tingkat keunggulan tersebut untuk memenuhi keinginan pelanggan (Tjiptono, 2014:268). 


\section{Unsur-Unsur Kualitas Pelayanan}

Menurut Daryanto dan Setyobudi (2014), unsur-unsur kualitas pelayanan terdiri dari: (1) penampilan, (2) tepat waktu dan janji, (3) kesediaan melayani, (4) pengetahuan dan keahlian, (5) kesopanan dan ramah tamah, (6) kejujuran dan kepercayaan, (7) kepastian hukum, (8) keterbukaan, (9) efisien, (10) biaya, (11) tidak rasial, dan (12) kesederhanaan.

\section{Dimensi Kualitas Pelayanan}

Dalam rangka memudahkan penilaian dan pengukuran kualitas pelayanan, dikembangkan alat ukur yang disebut servqual (service quality). Pada awalnya, servqual yang dikembangkan oleh Parasuraman, et al. (1985) dalam Tjiptono (2014:282) terdiri dari sepuluh dimensi, yaitu (1) reliabilitas (reliability), (2) responsivitas (responsiveness), (3) kompetensi (competence), (4) akses (access), (5) kesopanan (courtesy), (6) komunikasi (communication), (7) kredibilitas (credibility), (8) keamanan (security), (9) kemampuan memahami pelanggan, dan (10) bukti fisik (tangibles).

Pada riset berikutnya, Parasuraman, et al. (1988) dalam Tjiptono (2014:282) menyempurnakan dan merangkum sepuluh dimensi tersebut. Kompetensi, kesopanan, kredibilitas dan keamanan disatukan menjadi jaminan (assurance), sedangkan akses, komunikasi dan kemampuan memahami pelanggan dikategorikan sebagai empati (empathy).

Berdasarkan hal tersebut, Parasuraman, et al. (1988) dalam Tjiptono (2014:282) menjelaskan bahwa kualitas pelayanan terdiri dari lima dimensi berikut.

1. Keandalan (reliability), yaitu kemampuan untuk memberikan layanan yang dijanjikan dengan segera, akurat dan memuaskan.

2. Daya tanggap (responsiveness), yaitu keinginan untuk membantu dan melayani pelanggan dengan tanggap.

3. Jaminan (assurance), yaitu dimensi yang mencakup pengetahuan, kompetensi, kesopanan dan sifat dapat dipercaya yang dapat melindungi pelanggan dari bahaya, risiko dan keraguan.

4. Empati (empathy), yaitu dimensi yang meliputi kemudahan dalam menjalin relasi dan komunikasi yang baik, serta kemampuan dalam memperhatikan dan memahami kebutuhan individual pelanggan.

5. Bukti fisik (tangibles), yaitu dimensi yang meliputi fasilitas fisik, perlengkapan, pegawai dan sarana komunikasi. Dimensi ini merepresentasikan kemampuan perusahaan dalam menunjukkan eksistensinya kepada pihak eksternal. 


\section{Brand Image}

American Marketing Association dalam Kotler dan Keller (2009) mendefinisikan merek sebagai nama, istilah, tanda, lambang, desain, atau kombinasinya yang difungsikan untuk mengidentifikasi dan mendiferensiasikan barang/jasa suatu perusahaan dari pesaingnya. Kotler dan Keller (2009) mendefinisikan citra merek sebagai persepsi dan keyakinan konsumen yang dicerminkan oleh asosiasi dalam memorinya. Kotler dan Keller (2009) menjelaskan bahwa merek merupakan seperangkat keyakinan, ide dan kesan seseorang terhadap suatu merek.

\section{Faktor-Faktor yang Mempengaruhi Brand Image}

Menurut Schiffman dan Kanuk (2010), citra merek dapat dipengaruhi oleh faktorfaktor berikut.

1) Kualitas, yakni kualitas produk yang ditawarkan oleh produsen bermerek tertentu.

2) Dapat dipercaya atau diandalkan, yaitu terkait pendapat atau kesepakatan yang dibentuk oleh masyarakat atas suatu produk.

3) Kegunaan, yaitu terkait fungsi suatu produk yang bisa dimanfaatkan konsumen.

4) Pelayanan, yaitu terkait tugas produsen dalam melayani konsumennya.

5) Resiko, yaitu terkait besar kecilnya akibat (untung/rugi) yang mungkin dialami konsumen.

6) Harga, yaitu terkait jumlah uang yang dikeluarkan konsumen untuk suatu produk.

7) Citra dari merek itu sendiri, yaitu pandangan, kesepakatan, dan informasi terkait merek produk tertentu.

\section{Dimensi Brand Image (Citra Merek)}

Menurut Kotler dan Amstrong (2012), citra merek dapat diukur dengan mengacu pada aspek-aspek berikut.

1. Kekuatan (Strength)

Strength mengarah pada berbagai atribut fisik dari suatu merek yang diyakini sebagai sebuah superioritas atas merek lainnya. Aspek ini meliputi penampilan fisik produk, fungsi fasilitas produk, harga produk, dan penampilan fasilitas pendukung produk.

2. Keunikan (Uniqueness)

Uniqueness merupakan dimensi yang menunjukkan kemampuan untuk membedakan suatu merek dari merek lainnya. Kesan unik ini menunjukkan adanya diferensiasi antara produk yang satu dan produk yang lainnya. Aspek ini meliputi variasi layanan dan harga 
serta diferensiasi.

3. Keunggulan (Favourable)

Favourable mengarah pada kemampuan suatu merek untuk mudah diingat oleh pelanggan. Aspek ini meliputi kemudahan merek produk untuk diucapkan, kemampuan merek untuk tetap diingat pelanggan, dan kesesuaian antara kesan merek di benak pelanggan dengan citra yang diinginkan perusahaan atas merek yang bersangkutan.

\section{Customer Relationship Management}

Menurut Alma (2011), Customer Relationship Management (CRM) merupakan proses untuk mendapatkan, mempertahankan dan meningkatkan hubungan yang menguntungkan dengan pelanggan dalam rangka menciptakan nilai dan kepuasan pelanggan serta memaksimalisasi keuntungan perusahaan terkait keunggulan bersaing dan memperhatikan mutu produk agar pelanggan dapat mencapai kepuasan prima. Menurut Kotler dan Amstrong (2012), manajemen hubungan pelanggan adalah proses untuk membangun dan menjaga hubungan dengan pelanggan melalui penyampaian nilai superior dan kepuasan pelanggan.

\section{Manfaat Customer Relationship Management}

Menurut Tunggal (2000:10) dalam Achmad (2010), manfaat dari customer relationship management antara lain sebagai berikut.

1. Mendorong loyalitas pelanggan

Customer relationship management memungkinkan perusahaan untuk mendayagunakan informasi dari semua titik kontak dengan pelanggan, mulai dari web, call center, hingga staf pemasaran dan pelayanan di lapangan. Konsistensi dan aksesibilitas informasi mengenai kondisi pelanggan di lapangan ini memungkinkan perusahaan untuk senantiasa memberikan pelayanan yang lebih baik kepada pelanggan.

2. Mengurangi biaya

Pemanfaatan teknologi dalam customer relationship management dapat mengurangi biaya tertentu bagi perusahaan melalui sebuah skema program pemasaran terspesifikasi dan terfokus kepada pelanggan yang tepat di waktu yang tepat.

3. Meningkatkan efisiensi operasional

Otomatisasi proses pelayanan dapat mengurangi risiko turunnya kualitas pelayanan, sekaligus mengurangi beban cash flow. Penggunaan teknologi web dan call center akan mengurangi hambatan birokrasi dan biaya serta proses administrasi yang ditimbulkannya. 
4. Meningkatkan time to market

Customer relationship management memungkinkan perusahaan untuk membawa produknya ke pasar secara lebih cepat dengan memanfaatkan data dan informasi yang lebih baik mengenai pelanggan dan trend pembeliannya, serta membuat perencanaan yang lebih baik melalui integrasi dengan aplikasi Enterprise Resource Planning (ERP).

5. Meningkatkan pendapatan

Customer relationship management memungkinkan perusahaan untuk melakukan penjualan dan menyediakan pelayanan melalui website, sehingga menciptakan peluang yang lebih besar bagi perusahaan untuk merambah pasar yang lebih luas dan global.

\section{Tahapan Costumer Relationshiop Management (CRM)}

Menurut Kalakota dan Robinson (2001) dalam Achmad (2010), terdapat tiga tahapan customer relationship management, yaitu sebagai berikut.

1. Memperoleh pelanggan baru, yakni dengan mempromosikan keunggulan produk kepada publik melalui berbagai media.

2. Meningkatkan keuntungan, yakni dengan mendorong terciptanya produk pelengkap dan penjualan produk yang lebih baik dari produk yang dimiliki pelanggan.

3. Mempertahankan pelanggan yang memberi keuntungan, yakni dengan menawarkan apa yang dibutuhkan pelanggan tertentu untuk memenuhi kebutuhan dan keinginannya.

Sheth dan Parvatiyar (2002) menyatakan bahwa customer relationship management terdiri dari program-program sebagai berikut.

\section{Continuity Marketing}

Sheth dan Parvatiyar (2002) menyatakan bahwa program continuity marketing berfungsi untuk membangun dan memelihara loyalitas pelanggan melalui pelayanan khusus jangka panjang dengan cara mempelajari karakteristik setiap pelanggan untuk meningkatkan nilai. Menurut Oesman (2010), program continuity marketing biasanya berbentuk program kartu keanggotaan atau kartu loyalitas yang akan memungkinkan konsumen untuk menerima pelayanan khusus, diskon, dan poin untuk upgrades, serta menerima program penjualan silang.

2. One to One Marketing

Program ini merupakan program pemasaran berpendekatan individual untuk memenuhi kebutuhan dan keinginan konsumen.

3. Partnering Program 
Program ini merupakan program untuk menjalin kerjasama dengan perusahaan penyedia produk lain dalam rangka mengikat konsumen.

\section{Dimensi Customer Relationship Management}

Menurut Kotler dan Keller (2009), customer relationship management terdiri dari empat aktivitas, yaitu sebagai berikut.

1. Identify, yaitu mengidentifikasi pelanggan, misalnya dengan mengelola database dan membuat kartu member.

2. Acquire, yaitu mengakuisisi pelanggan dengan memberikan semua informasi kepada pelanggan, melayani dengan ramah dan sopan, menginformasikan promo melalui pesan singkat.

3. Retain, yaitu mempertahankan pelanggan dengan melakukan pemberian reward dan diskon.

4. Develop, yaitu upaya untuk mengembangkan atau mendapatkan pelanggan baru.

\section{Loyalitas Pelanggan}

Menurut Peter dan Olson (2005) dalam Achmad (2010), loyalitas pelanggan adalah dorongan untuk membeli suatu produk secara berulang-ulang dan membangun kesetiaan terhadapnya melalui proses pembelian yang berulang-ulang tersebut. Kotler dan Keller (2009) menyatakan bahwa loyalitas tidak hanya diukur dari banyaknya pembelian oleh konsumen, tetapi juga diukur dari banyaknya pembelian berulang oleh konsumen.

Menurut Kotler, et al. (1999) dalam Wijaya dan Thio (2008), loyalitas pelanggan dapat didefinisikan sebagai besarnya kesediaan pelanggan untuk membeli kembali dan menjadi partner perusahaan. Sementara itu, Oliver (1999) dalam Achmad (2010) menyatakan bahwa loyalitas pelanggan adalah komitmen pelanggan untuk melakukan pembelian ulang atas suatu produk secara konsisten di masa mendatang, meskipun pengaruh kondisi dan usaha pemasaran berpotensi mengubah perilaku.

\section{Tingkatan Loyalitas Pelanggan}

Menurut Hill (2007) dalam Hurriyati (2010), loyalitas memiliki enam tingkatan, yaitu sebagai berikut.

1. Suspect, yaitu semua pembeli produk yang menyadari adanya produk, tetapi terkadang tidak berkecenderungan untuk membeli. 
2. Prospect, yaitu pelanggan potensial yang tertarik pada perusahaan, tetapi belum mengambil tindakan untuk berbisnis dengan perusahaan.

3. Customer, yaitu pembeli produk yang tidak loyal terhadap perusahaan, meski telah membeli beberapa kali.

4. Client, yaitu konsumen yang melakukan pembelian ulang dan menunjukkan loyalitas terhadap perusahaan, tetapi cenderung lebih pasif daripada aktif terhadap perusahaan.

5. Advocates, yaitu client yang memberikan dorongan positif kepada perusahaan dengan merekomendasikannya kepada orang lain.

6. Partners, yaitu pelanggan yang memiliki hubungan yang sangat erat dan saling menguntungkan.

\section{Dimensi Loyalitas Pelanggan}

Menurut Griffin (2002:74), loyalitas pelanggan memiliki dimensi berikut ini.

1. Melakukan pembelian ulang secara teratur.

2. Menunjukkan daya tarik pesaing, yakni tidak mudah terpengaruh oleh persaingan dari perusahaan sejenis lainnya.

3. Menganjurkan produk kepada orang lain

4. Bersedia membayar lebih tinggi apabila kualitas lebih baik

\section{Keterkaitan Antarvariabel}

\section{Keterkaitan antara Kualitas Pelayanan dan Loyalitas Pelanggan}

Hasil penelitian yang dilakukan Pramana dan Rastini (2016) serta Mulyaningsih (2013) membuktikan bahwa kualitas pelayanan berpengaruh positif dan signifikan terhadap loyalitas pelanggan. Nariswari dan Iriawan (2012) juga menemukan bahwa kualitas pelayanan berpengaruh signifikan terhadap loyalitas pelanggan. Menurut Kotler dan Keller (2009), kualitas pelayanan yang baik akan menimbulkan kepuasan konsumen yang akan mendorong konsumen tersebut untuk melakukan pembelian ulang. Hal tersebut pada akhirnya akan meningkatkan loyalitas konsumen.

$\mathrm{H}_{1}$ : Kualitas pelayanan berpengaruh positif dan signifikan terhadap loyalitas pelanggan Indomaret Kelurahan Padurenan, Bekasi Timur.

\section{Keterkaitan antara Brand Image dan Loyalitas Pelanggan}

Hasil penelitian Sondakh (2014) serta Widiana dan Sukawati (2016) menunjukkan bahwa citra merek berpengaruh positif dan signifikan terhadap loyalitas pelanggan. Menurut 
Kotler dan Keller (2009), citra merek merupakan persepsi dan keyakinan konsumen yang dicerminkan oleh asosiasi dalam memorinya. Setiadi (2003) dalam Sondakh (2014) menyatakan bahwa suatu merek bercitra positif akan menarik konsumen untuk melakukan pembelian dan pembelian ulang. Hal tersebut pada akhirnya akan meningkatkan loyalitas konsumen.

$\mathrm{H}_{2}$ : Brand image berpengaruh positif dan signifikan terhadap loyalitas pelanggan Indomaret Kelurahan Padurenan, Bekasi Timur.

\section{Keterkaitan antara Customer Relationship Management dan Loyalitas Pelanggan}

Hasil penelitian Mulyaningsih (2013) dan Kalalo (2013) menunjukkan bahwa customer relationship management berpengaruh positif dan signifikan terhadap loyalitas pelanggan. Hal tersebut menunjukkan bahwa semakin baik customer relationship management di dalam suatu perusahaan, maka semakin baik pula tingkat loyalitas pelanggan terhadap produk/jasa dari perusahaan tersebut. Hasil penelitian yang dilakukan oleh Achmad (2010) juga membuktikan bahwa customer relationship management yang diproksikan dengan komitmen dan komunikasi memiliki pengaruh yang positif dan signifikan terhadap loyalitas pelanggan.

$\mathrm{H}_{3}$ : Customer relationship management berpengaruh positif dan signifikan terhadap loyalitas pelanggan Indomaret Kelurahan Padurenan, Bekasi Timur.

\section{Kerangka Analisis}

Berikut ini merupakan kerangka analisis penelitian.

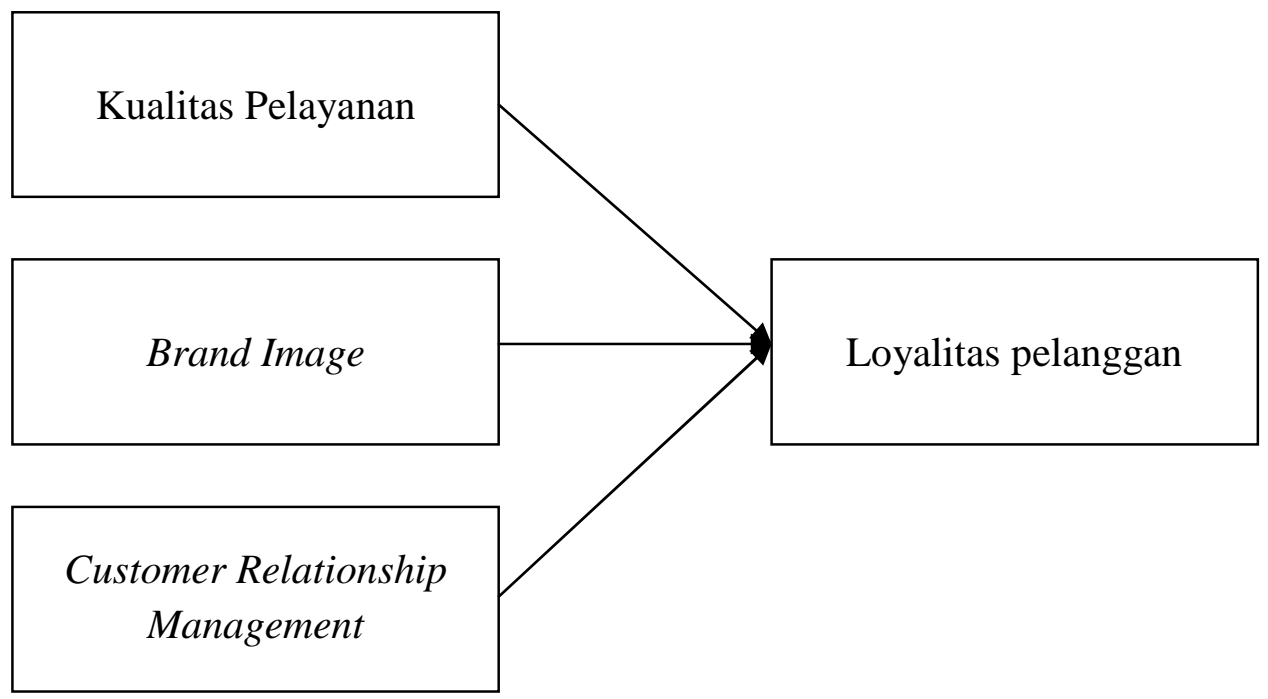

Gambar 1. Kerangka Analisis 


\section{METODE PENELITIAN}

\section{Sumber dan Jenis data}

Data dalam penelitian ini bersumber dari data primer berupa penyebaran kuesioner. Jenis data yang digunakan merupakan data cross section.

\section{Populasi dan Sampel}

Populasi dalam penelitian ini adalah pelanggan Indomaret di Kelurahan Padurenan, Bekasi Timur. Populasi penelitian ini berjumlah tidak terbatas. Pengambilan sampel dilakukan dengan menggunakan metode purposive sampling dan quota sampling. Berikut ini merupakan kriteria sampling.

1. Responden telah menjadi member Indomaret yang dibuktikan dengan kepemilikan terhadap member card Indomaret Kelurahan Padurenan, Bekasi Timur.

2. Responden telah melakukan pembelian ulang minimal dua kali di Indomaret Kelurahan Padurenan, Bekasi Timur.

Dengan populasi tak terbatas, jumlah sampel penelitian dihitung menggunakan rumus Sugiyono (2012:79) berikut.

$$
\mathrm{n}=\frac{\mathrm{z}^{2}}{4(\text { Moe })^{2}}
$$

Keterangan:

$$
\begin{array}{ll}
\mathrm{n} & =\text { Jumlah sampel } \\
\mathrm{Z} & =\text { Tingkat distribusi normal pada taraf } 5 \%=1,96 \% \\
\text { Moe } & =\text { Margin of error, ditetapkan sebesar } 10 \%
\end{array}
$$

Dengan menggunakan rumus tersebut, jumlah sampel yang diteliti adalah 96,04 responden yang dibulatkan menjadi 100 responden.

\section{Definisi Operasional Variabel}

Definisi operasional variabel yang digunakan dalam penelitian ini, yaitu sebagai berikut. 
Tabel 1. Definisi Operasional

\begin{tabular}{|c|c|c|}
\hline Variabel & Definisi Operasional & Indikator \\
\hline $\begin{array}{l}\text { Kualitas } \\
\text { Pelayanan }\end{array}$ & $\begin{array}{l}\text { Seberapa baik pelayanan yang } \\
\text { diberikan perusahaan kepada } \\
\text { konsumennya. }\end{array}$ & $\begin{array}{l}\text { - Bukti langsung (tangibles) } \\
\text { - Keandalan (reliability) } \\
\text { - Daya tanggap (responsiveness) } \\
\text { - Jaminan (assurance) } \\
\text { Sumber: Parasuraman, et al. (1988) } \\
\quad \text { dalam Tjiptono (2014:282) }\end{array}$ \\
\hline Brand Image & $\begin{array}{l}\text { Gambaran atas suatu merek di } \\
\text { benak konsumen. }\end{array}$ & $\begin{array}{l}\text { - Kekuatan (strength) } \\
\text { - Keunikan (uniqueness) } \\
\text { - Keunggulan (favourable) } \\
\text { Sumber: Kotler dan Amstrong (2012) }\end{array}$ \\
\hline $\begin{array}{l}\text { Customer } \\
\text { Relationship } \\
\text { Management }\end{array}$ & $\begin{array}{l}\text { Pengelolaan hubungan antara } \\
\text { pihak manajemen perusahaan } \\
\text { dan pelanggannya. }\end{array}$ & $\begin{array}{l}\text { - Mengidentifikasi pelanggan (identify) } \\
\text { - Mempertahankan pelanggan (retain) } \\
\text { - Mengembangkan pelanggan (develop) } \\
\text { Sumber: Kotler dan Keller (2009) }\end{array}$ \\
\hline $\begin{array}{l}\text { Loyalitas } \\
\text { Pelanggan }\end{array}$ & $\begin{array}{l}\text { Tingkat kesetiaan pelanggan } \\
\text { terhadap suatu produk. }\end{array}$ & $\begin{array}{l}\text { - Melakukan pembelian ulang secara } \\
\text { teratur (make regular purchases) } \\
\text { - Menunjukan daya tarik pesaing } \\
\text { (cooperation) } \\
\text { - Menganjurkan produk kepada orang } \\
\text { lain (word of mouth) } \\
\text { - Bersedia membayar lebih tinggi } \\
\text { (switching cost) } \\
\text { Sumber: Griffin (2002:74) }\end{array}$ \\
\hline
\end{tabular}

\section{Metode Analisis}

Penelitian ini menggunakan metode analisis regresi linear berganda untuk menganalisis pengaruh kualitas pelayanan, brand image dan customer relationship management terhadap loyalitas pelanggan Indomaret Kelurahan Padurenan, Bekasi Timur.

\section{HASIL PENELITIAN DAN PEMBAHASAN}

\section{Hasil Uji Instrumen}

Hasil uji validitas menunjukkan bahwa semua butir pernyataan kuesioner bersifat valid karena memiliki $r_{\text {hitung }}$ yang lebih besar dari $r_{\text {tabel. }}$. Sementara itu, hasil uji reliabilitas menunjukkan bahwa semua semua konsep pengukur dari masing-masing variabel bersifat reliabel karena mempunyai nilai cronbach's alpha yang berada di atas nilai minimum cronbach's alpha. 


\section{Hasil Uji Asumsi Klasik}

Uji asumsi klasik yang dilakukan terdiri dari uji normalitas, multikolinearitas, heteroskedastisitas dan autokorelasi. Hasil uji normalitas menunjukkan bahwa data penelitian terdistribusi normal karena memiliki asymp. sig. (2-tailed) yang lebih besar daripada $\alpha$ sebesar 0,05. Sementara itu, hasil uji multikolinearitas menunjukkan bahwa tidak terjadi multikolinearitas dalam model ini karena setiap variabel independen dalam penelitian memiliki nilai tolerance $>0,1$ dan nilai $\mathrm{VIF}<10$.

Hasil uji heteroskedasatisitas dengan menggunakan scatterplot menunjukkan bahwa tidak terjadi heteroskedastisitas dalam model ini karena titik-titik pada scatterplot menyebar dengan pola yang tidak jelas di atas dan di bawah angka 0 pada sumbu Y. Sementara itu, hasil uji autokorelasi menunjukkan bahwa tidak terjadi autokorelasi dalam model ini karena kriteria $\mathrm{dU}<\mathrm{DW}<4-\mathrm{dU}$ telah terpenuhi.

\section{Hasil Uji Regresi Linear Berganda}

Berikut ini merupakan persamaan regresi linear berganda yang diperoleh dari penelitian ini.

$$
Y=3,346+0,338 X_{1}+0,298 X_{2}+0,222 X_{3}
$$

Keterangan:

$$
\begin{aligned}
& \mathrm{Y}=\text { Loyalitas Pelanggan } \\
& \mathrm{X}_{1}=\text { Kualitas Pelayanan } \\
& \mathrm{X}_{2}=\text { Brand Image } \\
& \mathrm{X}_{3}=\text { Customer Relationship Management }
\end{aligned}
$$

\section{Hasil Uji Kelayakan Model}

Hasil uji $\mathrm{F}$ menemukan nilai $\mathrm{F}_{\text {hitung }}$ yang positif dengan signifikansi yang lebih kecil daripada $\alpha$ sebesar 0,05, sehingga kualitas pelayanan, brand image dan customer relationship management secara simultan berpengaruh positif dan signifikan terhadap loyalitas pelanggan. Hal tersebut menunjukkan bahwa model penelitian ini bersifat layak.

Sementara itu, besarnya koefisien determinasi dari model ini adalah 0,502. Hal tersebut menunjukkan bahwa kualitas pelayanan, brand image dan customer relationship management berkontribusi sebesar 50,2\% dalam mempengaruhi loyalitas pelanggan, sedangkan 49,8\% sisanya dipengaruhi oleh variabel lainnya yang tidak dijelaskan dalam penelitian ini. 


\section{Hasil Uji Hipotesis 1}

Hasil uji hipotesis 1 menunjukkan bahwa kualitas pelayanan memiliki nilai t yang positif dengan signifikansi yang lebih kecil dari $\alpha$ sebesar 0,05 , sehingga kualitas pelayanan berpengaruh positif dan signifikan terhadap loyalitas pelanggan Indomaret Kelurahan Padurenan, Bekasi Timur. Hasil ini sejalan dengan hasil penelitian Pramana dan Rastini (2016) serta Mulyaningsih (2013). Pengaruh positif dan signifikan kualitas pelayanan terhadap loyalitas pelanggan menunjukkan bahwa semakin tinggi kualitas pelayanan yang diberikan perusahaan kepada konsumen/pelanggan, maka semakin tinggi pula loyalitas konsumen/pelanggan tersebut terhadap barang/jasa perusahaan tersebut. Menurut Kotler dan Keller (2009), hal ini terjadi karena kualitas pelayanan yang baik akan menimbulkan kepuasan konsumen yang akan mendorong konsumen tersebut untuk melakukan pembelian ulang. Hal tersebut pada akhirnya akan meningkatkan loyalitas konsumen.

Kualitas pelayanan merupakan ukuran atas seberapa bagus pelayanan yang diberikan perusahaan dan seberapa sesuai layanan yang diberikan tersebut dengan ekspektasi pelanggan (Tjiptono dan Chandra, 2012). Oleh karena itu, semakin tinggi kualitas pelayanan yang diberikan perusahaan kepada konsumen, maka semakin tinggi kemampuan perusahaan tersebut untuk memenuhi ekspektasi konsumennya, sehingga konsumen tersebut akan semakin terdorong untuk melakukan pembelian ulang dalam rangka menunjukkan loyalitasnya kepada perusahaan.

\section{Hasil Uji Hipotesis 2}

Hasil uji hipotesis 2 menunjukkan bahwa brand image memiliki nilai t yang positif dengan signifikansi yang lebih kecil dari $\alpha$ sebesar 0,05 , sehingga brand image berpengaruh positif dan signifikan terhadap loyalitas pelanggan Indomaret Kelurahan Padurenan, Bekasi Timur. Artinya, semakin baik brand image dari suatu produk/jasa, maka semakin tinggi loyalitas pelanggan terhadap produk/jasa tersebut. Hal ini sejalan dengan hasil penelitian Sondakh (2014) serta Widiana dan Sukawati (2016). Setiadi (2003) dalam Sondakh (2014) menyatakan bahwa suatu merek bercitra positif akan menarik konsumen untuk melakukan pembelian dan pembelian ulang. Hal tersebut pada akhirnya akan meningkatkan loyalitas konsumen. Menurut Tu, et al. (2013), perusahaan harus memiliki brand image yang positif untuk membangun hubungan jangka panjang yang saling menguntungkan dengan pelanggan dalam rangka menciptakan loyalitas pelanggan.

Menurut Kotler dan Amstrong (2012), produk dengan brand image yang baik merupakan produk yang memiliki kekuatan pada atribut fisik, keunikan yang mampu 
membedakannya dari merek lain yang sejenis dan keunggulan yang mampu membuatnya mudah diingat oleh pelanggan. Ketiga dimensi itulah yang mampu membuat suatu produk unggul dari pesaingnya di mata pelanggannya, sehingga mendorong pelanggan untuk senantiasa loyal dalam menggunakannya.

\section{Hasil Uji Hipotesis 3}

Hasil uji hipotesis 3 menunjukkan bahwa customer relationship management memiliki nilai t yang positif dengan signifikansi yang lebih kecil dari $\alpha$ sebesar 0,05 , sehingga customer relationship managament berpengaruh positif dan signifikan terhadap loyalitas pelanggan Indomaret Kelurahan Padurenan, Bekasi Timur. Artinya, semakin baik customer relationship management yang diterapkan dalam suatu perusahaan, maka semakin tinggi loyalitas pelanggan terhadap barang/jasa perusahaan tersebut. Hal ini sejalan dengan hasil penelitian Mulyaningsih (2013) dan Kalalo (2013). Hasil penelitian Achmad (2010) juga menunjukkan bahwa customer relationship management yang diproksikan dengan komitmen dan komunikasi memiliki pengaruh yang positif dan signifikan terhadap loyalitas pelanggan. Hal ini dikarenakan semakin baik kualitas customer relationship management yang diterapkan oleh suatu perusahaan, maka semakin baik pula hubungan antara perusahaan tersebut dengan pelanggannya, sehingga semakin tinggi tingkat kepuasan pelanggan. Hal tersebut akan mendorong pelanggan untuk melakukan pembelian ulang dan pada akhirnya akan menciptakan loyalitas di dalam diri pelanggan tersebut.

Menurut Alma (2011:296), customer relationship management dikembangkan untuk menciptakan keunggulan bersaing suatu perusahaan dalam rangka memberikan kepuasan yang prima bagi pelanggan. Perusahaan yang membangun hubungan yang baik dengan pelanggannya berarti telah memberikan kualitas pelayanan yang satu tingkat lebih baik kepada pelanggannya. Hal tersebut akan semakin meningkatkan kepuasan pelanggan, sehingga mendorong pelanggan tersebut untuk loyal kepada perusahaan. Tunggal (2000:10) dalam Achmad (2010) juga mengemukakan bahwa customer relationship management dapat bermanfaat untuk mendorong loyalitas pelanggan. Kalakota dan Robinson (2001) dalam Achmad (2010) juga menyatakan bahwa customer relationship management merupakan suatu kegiatan yang perlu dilakukan untuk mempertahankan pelanggan yang memberi keuntungan, yakni dengan menawarkan apa yang dibutuhkan oleh pelanggan tersebut untuk memenuhi kebutuhan dan keinginannya. 


\section{KESIMPULAN DAN SARAN}

\section{Kesimpulan}

Hasil penelitian ini menyimpulkan bahwa kualitas pelayanan, brand image dan customer relationship management secara parsial berpengaruh positif dan signifikan terhadap loyalitas pelanggan Indomaret Kelurahan Padurenan, Bekasi Timur.

\section{Saran}

Berdasarkan kesimpulan tersebut, berikut ini dikemukakan beberapa saran untuk perusahaan dan peneliti selanjutnya.

1. Perusahaan diharapkan senantiasa berupaya untuk meningkatkan kualitas pelayanannya kepada konsumen agar dapat meningkatkan loyalitas konsumen.

2. Perusahaan diharapkan senantiasa menjaga brand image-nya yang telah baik atau bahkan meningkatkan brand image tersebut agar dapat mendorong pelanggan untuk senantiasa loyal.

3. Perusahaan diharapkan senantiasa meningkatkan kualitas customer relationship management agar dapat senantiasa meningkatkan loyalitas pelanggan.

4. Peneliti selanjutnya diharapkan dapat memproksikan secara nyata aspek customer relationship management yang dapat mempengaruhi loyalitas pelanggan.

\section{DAFTAR PUSTAKA}

Achmad, T.A. 2010. Pengaruh Customer Relationship Marketing Terhadap Loyalitas Pengguna Matahari Club Card (MCC) Pada Matahari Department Store Mal Ska Pekanbaru. Jurnal Ekonomi. 18(4).

Alma, B. 2011. Manajemen Pemasaran dan Pemasaran Jasa. Alfabeta. Bandung.

Daryanto dan I. Setyobudi. 2014. Konsumen dan Pelayanan Prima. Gava Media.Yogyakarta.

Griffin, J. 2002. Customer Loyalty: How to Earn It, How to Keep It. Jossey-Bass. San Fransisco.

Hurriyati, R. 2010. Bauran Pemasaran dan Loyalitas Konsumen. Alfabeta. Bandung.

Kalakota, R. dan M. Robinson. 2001. E-Business 2.0: Roadmap for Success. Addison-Wesley Longman. Boston.

Kalalo, R.E. 2013. Customer Relationship Management dan Kualitas Pelayanan terhadap Loyalitas Konsumen PT. Matahari dept.store, Manado. Jurnal EMBA. 1(4): 15531561. 
Kotler, P., J. Bowen dan J. Makens. 1999. Marketing for Hospitality and Tourism. International Edition. Prentice Hall. New Jersey.

dan K.L. Keller. 2009. Marketing Management. $13^{\text {th }}$ Ed. Pearson Prentice Hall. New Jersey. Terjemahan B. Sabran. 2009. Manajemen Pemasaran. Erlangga. Jakarta.

dan G. Amstrong. 2012. Principle Of Marketing. Global Edition. Pearson Prentice Hall. New Jersey. Terjemahan A. Sindoro. 2012. Prinsip-Prinsip Pemasaran. Edisi 14. Erlangga. Jakarta.

Mulyaningsih. 2013. Customer Relationship Management dan Kualitas Layanan Pengaruhnya terhadap Loyalitas Pelanggan pada PT Pandu Siwi Sentosa Manado. Jurnal EMBA. 1(4): 1729-1737.

Nariswari, R. dan N. Iriawan. 2012. Analisis Pengaruh Kualitas Pelayanan, Kepuasan Nasabah dan Kepercayaan terhadap Loyalitas Nasabah Flexi Mobile Broadband di Wilayah Surabaya dengan Pendekatan SEM Bayesian. Jurnal Sains Dan Seni ITS. $1(1)$.

Oliver, R.L. 1999. Whence Consumer Loyalty? Journal of Marketing. 63: 33-44.

Parasuraman, A., V.A. Zeithaml dan L.L. Berry. 1985. A Conceptual Model of Service Quality and Its Implication for Future Research. Journal of Marketing. 49(4): 41-50.

Parasuraman, A., V.A. Zeithaml dan L.L. Berry. 1988. SERVQUAL: A Multiple-Item Scale for Measuring Consumer Perceptions of Service Quality. Journal of Retailing. 64(1): $12-40$.

Peter, J.P. dan J.C. Olson. 2005. Consumer Behaviour and Marketing Strategy. 7th Edition. McGraw-Hill. New York.

Pramana, I.G.Y. dan N.M. Rastini. 2016. Pengaruh Kualitas Pelayanan terhadap Kepercayaan Nasabah dan Loyalitas Nasabah Bank Mandiri Cabang Veteran Denpasar Bali. EJurnal Manajemen Unud. 5(1): 706-733.

Ratnasari, R.T. dan M.H. Aksa. 2016. Teori dan Kasus Manajemen Pemasaran Jasa. Ghalia Indonesia. Bogor.

Schiffman, L.G. dan L.L. Kanuk. 2010. Consumer Behavior. 10th Edition. Pearson Prentice Hall. New Jersey.

Setiadi, N.J. 2003. Perilaku Konsumen: Konsep dan Implikasi untuk Strategi dan Penelitian Pemasaran. Prenada Media. Jakarta.

Sheth, J.N. and A. Parvatiyar. 2002. Evolving Relationship Marketing into a Discipline. Journal of Relationship Marketing. 1(1)1-34.

Sondakh, C. 2014. Kualitas Layanan, Citra Merek dan Pengaruhnya terhadap Kepuasan Nasabah dan Loyalitas Nasabah Tabungan: Studi pada Nasabah Taplus BNI Cabang Manado. Jurnal Riset Bisnis dan Manajemen. 3(1): 19-32. 
Sugiyono. 2012. Metode Penelitian Manajemen. Alfabeta. Bandung.

Tjiptono, F. 2014. Pemasaran Jasa: Prinsip, Penerapan dan Penelitian. Andi Offset. Yogyakarta.

Tjiptono, F. dan G. Chandra. 2012. Pemasaran Strategik. Edisi Dua. Andi. Yogyakarta.

Top Brand Awards. 2017. Top Brand Index. http://www.topbrand-award.com. 18 Februari 2017 (09:00).

Tu, Y.T., M.L. Li dan H.C. Chih. 2013. An Empirical Study of Corporate Brand Image, Customer Perceived Value and Satisfaction on Loyalty in Shoe Industry. Journal of Economics and Behavioral Studies. 5(7): 469-483.

Tunggal, A.W. 2000. Konsep Dasar Customer Relationship Management. Harvarindo. Jakarta.

Widiana, I.W.P. dan T.G.R. Sukawati. 2016. Pengaruh Kualitas Produk dan Citra Merek terhadap Loyalitas Konsumen Pasta Gigi Pepsodent PT Unilever. E-Jurnal Manajemen Unud. 5(4): 1942-1968.

Wijaya, S. dan S. Thio. 2008. Implementasi Membership Card dan Pengaruhnya dalam Meningkatkan Loyalitas Pengunjung Restoran di Surabaya. Skripsi. Fakultas Ekonomi Universitas Kristen Petra. 